carrying people bent on peaceful purposes can enjoy the right of legal free passage. A century ago, of course, sea passage (through the Dardanelles, for example) was at the centre of these disputes. Aircraft have now taken the place of ships, but the contentiousness of disputed rights of passage has not abated. Last Monday, British Airways planned to land an aircraft at Orly airport, in south-suburban Paris, in defiance of a French declaration that it would not be allowed to land. Confrontation was avoided (and the disputed flight postponed until not later than the end of June) only after the respective transport ministers spent the weekend on the telephone to each other.

In reality, this dispute is not so much a test of the belligerence of the governments of Britain and France as of the resolution of the European Union (EU) in its pursuit of free competition. Not so long ago, ten out of the 12 present members of the EU maintained a national passenger airline to carry their flags to distant parts of the world, but also to parlay landing rights for their aircraft from governments elsewhere. The costs of these programmes were huge; they were met partly by European air travellers, who paid (and still pay) some of the highest air fares in the world, and partly by the same people in their role as taxpayers, who made possible the direct subsidy of European airlines. The dispute between Britain and France this week arises from the European Commission's efforts to make Europe's airline industry more competitive.

The nature of the dispute shows how much there is still to do. A truly competitive European airline business would be simply organized; there would be a number of airlines owned privately, by shareholders, strict regulation of safety and traffic by a transnational authority and some arrangement for allocating landing slots at European airports to those who would make the best use of them (perhaps by annual auctions).

The commission is struggling towards that goal, but only slowly. In the Anglo-French dispute, it has merely concluded that Orly airport, now used exclusively by aircraft serving French domestic routes, is an anti-competitive French fiefdom, and has awarded British aircraft access (as well as the right to carry passengers onwards to Lyons and Marseilles). Three British airlines are anxious to get started. Subplots in the dispute include British resentment (matched elsewhere in Europe) of a French plan to increase the capital of nationally owned Air France in a manner that will be indistinguishable from a subsidy and French demands for more landing slots at London airports.

It is some comfort to know that there will not now be a shooting war, but the first lesson to be learned from this affair is that it is absurd that the EU has so engineered matters that it is involved in the details of which aircraft can land, or fly to, where. It does not have the power to insist that nationalized airlines should be denationalized, but it can forbid subsidies absolutely, and should do so. Similarly, it can (as the Orly case shows) intervene on airport access, but should go the whole hog and devise a Europe-wide system for allocating landing slots to airlines able to make good use of them. Then it should sit back and watch Europe's airline industry become efficient.

\section{Back to Bretton Woods}

A scheme for reintroducing fixed international exchange rates is unlikely to succeed in the near future.

Mr Paul Volcker, the chairman of the Federal Reserve Board (or central bank) in the United States, is plainly an ambitious man: according to The Wall Street Journal last week, he is leading a group of central bankers seeking a way back to Bretton Woods, the system of fixed exchange rates the Western world devised in the closing months of the Second World War. The arrangement served the international community reasonably well until it was abandoned in 1971, largely because of the inability of the United States to keep the US dollar strong and to fight the Vietnam War at the same time. But Volcker's ambition is not easily distinguished from nostalgia, and is unlikely to be satisfied.

By all accounts, the Volcker group has already concluded that bringing back Bretton Woods would require of all participating governments a remarkable degree of financial discipline. They would have to keep their budgets nearly in balance and reduce their accumulated debts so that fiscal measures (taxation) could again become effective regulators of their economies. The control of inflation would similarly be a central objective of policy, while, in due course, 'economic convergence' would become central. Volcker, of course, has rediscovered what the members of the European Union argued out at Maastricht at the end of 1992, the celebrated preconditions for a common European currency. The events of 1993, when Britain and Italy abruptly abandoned their fixed exchange rates, are a vivid illustration of what can go wrong with such arrangements.

Yet the nostalgia is understandable. There is little doubt that a large part of the impetus for the growth of world trade in the decades immediately after the Second World War was that governments and traders knew what their money was worth (barring the occasional traumatic devaluation). It is less pleasing that, by excluding the developing countries, Bretton Woods deprived them of a fair share in that growth, as well as of the financial assistance of organizations such as the International Monetary Fund. Now there are even bigger problems to be tackled, the inclusion of Russia, the republics and Central Europe in a unified system for example. And the world's currency traders have become skilled at telling when a currency is being supported at an artificial level, to their own great profit.

None of this implies that Volcker's enterprise should be discouraged. On the contrary, it will be valuable if central bankers are induced again to discover for themselves that the simplest way of giving the world sound money is to run it as if it were a unified place, with common goals and common policies for achieving them. But the place to start is with the here and now, with the continuing need for technical and financial assistance in Europe east of the Elbe, with the need for an understanding between the industrial West and China and with the need for prosperity in the developing world. 